\title{
Forum
}

PMLA invites members of the association to submit letters, printed and double-spaced, that comment on articles in previous issues or on matters of editor reserves the right to reject or edit Forum contributions and offers the $P M L A$ authors discussed in published letters an opportunity to reply. Occasionally the Forum contains letters on topics of broad interest written and submitted at the editor's request. The journal omits titles before persons' names, discourages footnotes, and does not consider any letter of more than one thousand words. Letters should be addressed to PMLA Forum, Modern Language Association, 26 Broadway, 3rd floor, New York, NY 10004-1789. general scholarly or critical interest. The

\section{Günter Grass's Nobel Lecture}

\section{TO THE EDITOR:}

As a lifelong member, I regularly look forward to receiving and reading the current PMLA number. The Nobel Lecture by Günter Grass was set both in English and in German ("To Be Continued ..." " "Fortsetzung folgt ...,", 115 [2000]: 292-309). This courtesy to the laureate and his readers who know German is to be applauded. The translator, Michael Henry Heim, is an accomplished English stylist. Still, I counted a few translation mistakes. On 297, right column, lines 4-6, Theodor Adorno's "und das frißt auch die Erkenntnis an" was omitted from the translation. In the same column "gray values" should perhaps be "checkered values" (line 23), "language I had all too sweepingly pronounced guilty" should be "language that had all too sweepingly been pronounced guilty" (lines 26-27), and "artlessness" should be "simplicity" (line 30). On 298, left column, lines 4-5, "Stunde Null" is not exactly "end of the postwar period" but rather "Point Zero." "Gottlosigkeit" means "agnosticism" or "ungodliness," not "godlessness" (299, right col., line 16).

The German version of the lecture contains typos as well, which PMLA informs me appeared in the original text provided by the Nobel Foundation. There was too much hurry involved. On 303, right column, line 18, "Die Lieblingscousin" should be "Der Lieblingscousin." On 306, left column, "der" is missing after "Humor" (line 7), and "im" is missing before "Sinne" (line 21). On the same page, right column, line 13, "Pater" should be "Pate." On 308 , left column, line 11 from the bottom, "ebracht" should be "gebracht."

The translator chose many felicitous phrases. and the eyesores I have listed are avoidable. Next time a proofreader who is waschecht ("dyed in the wool") ought to be involved.

Thank you for daring to print this criticism.

Christian Gellinek Münster, Germany

198 